\title{
Purpose, Pedagogy and Philosophy: "Being" an Online Lecturer
}

Dr Helen Coker

University of the Highlands and Islands Inverness College, Scotland

\begin{abstract}
Instructing online has become an increasingly common aspect of a university lecturer's role. While research has developed an understanding of the student learning experience, less attention has been paid to the role of the lecturer. This study observed the practice of university lecturers teaching in a range of undergraduate degree programmes in the United Kingdom. The lecturers' purpose, pedagogy, and philosophy emerged in the dialogic patterns of the online space. Practice was shaped by the lecturers' epistemological positioning and their cultural values and beliefs. The practice, which was observed across different modules, reflected the different positions lecturers took when they approached online teaching. The research highlights the way in which a lecturers' purpose, pedagogy, and philosophy are reflected in their online facilitation.
\end{abstract}

Keywords: online teaching, online lecturers, e-learning, online pedagogy, e-pedagogy 


\section{Introduction - What is the problem?}

As universities develop more online and blended programmes, working online is becoming an increasingly common occurrence for lecturers in higher education. Research has highlighted the key role that lecturers play in supporting student proficiency and participation in the online setting (Park, 2015; Stott, 2016). Effective facilitation of online modules supports student engagement (Arbaugh, 2014) and scaffolds student interactions (Cho \& Cho, 2014). Online students' value teaching presence and lecturer-student interaction (Kyei-Blankson, Ntuli, \& Donnelly, 2016). The current research explored the role of lecturers within a range of online undergraduate degree programmes.

Research, focusing on online learning in educational settings, has largely focused on the student rather than the lecturer (Arbaugh, 2014). Studies have explored students' loss of social and emotional cues in the online space (Guillaume et al., 2016; Slagter van Tyron \& Bishop, 2006), the challenges of creating social presence for learners (Kehrwald, 2008; Laffey, Lin, \& Lin, 2006), communities of inquiry (Akyol \& Garrison, 2011; Garrison, Anderson, \& Archer, 2000; Garrison, 2012; Joksimovic, Gasevic, Kovanovic, Adescope, \& Hatala, 2014; Pozzi, Ceregini, Ferlino, \& Persico, 2016), and the influence of motivation and self-efficacy (Kim, Glassman, \& Williams, 2015; Stott, 2016). These factors also influence the lecturer experience, posing new challenges due to online delivery, particularly when facilitating collaborative activities (Palloff \& Pratt, 2004). Lecturers are positioned differently to students as they are responsible for the learning of students within the module space. Unlike being in a classroom, online lecturers are often in different physical and temporal spaces to the students they are teaching. Many of the cues that lecturers use in face-to-face settings are lost, posing potential challenges for the online lecturer.

Lecturers working in university settings use a range of pedagogic approaches (Åkerlind, 2004); the approach taken influencing the learning of students in their classes (Karagiannopoulou \& Entwistle, 2013). Pedagogic and discipline beliefs, epistemology, and technological ability may also influence a lecturers' approach to facilitating online modules (Lameras, Levy, Paraskakis, \& Webber, 2012; Owens, 2012). Studies of e-learning in university settings have found similar pedagogic variation to the face-toface environment; transmission of information and dialogic or collaborative pedagogies being observed in both settings (González, 2010). This would suggest that not all lecturers approach online teaching with the same pedagogic underpinning, or the same technological know-how.

In institutions quick to take up online delivery, there are now a generation of experienced lecturers who have developed teaching approaches appropriate to the online setting. These lecturers work in a range of disciplines and are likely to hold a variety of pedagogic beliefs. The current study explored the teaching approaches of lecturers, when facilitating online collaborative activities. Lecturers taught on a range of modules within four undergraduate degree programmes at the same university. Focusing on the ways in which lecturers facilitated collaborative activities as part of the teaching process, this study observed practice as it was enacted in the online setting.

\section{Research Methodology and Methods}

Taking an ethnographic approach (Hammersley \& Atkinson, 2007), lecturers' online participation was observed as they taught online undergraduate modules. The observations focused particularly on the collaborative aspects of practice: the ways in which lecturers worked with students, or facilitated students to work with each other. The observation was iterative using data from the online space, 
interviews, and a focus group (Figure 1). The study observed the ways in which lecturers participated online, observing what they did through data drawn from online modules and gaining their perceptions of the experience through interviews and a focus group. The iterative approach created a rich observation of the lecturers' online practice. In keeping with the ethnographic stance, data gathered from the university learning management system was observed qualitatively (Cohen, Manion, \& Morrison, 2013) and a hybrid inductive-deductive approach (Fereday \& Muir-Cochrane, 2006) was taken when analysing interview and focus group data.

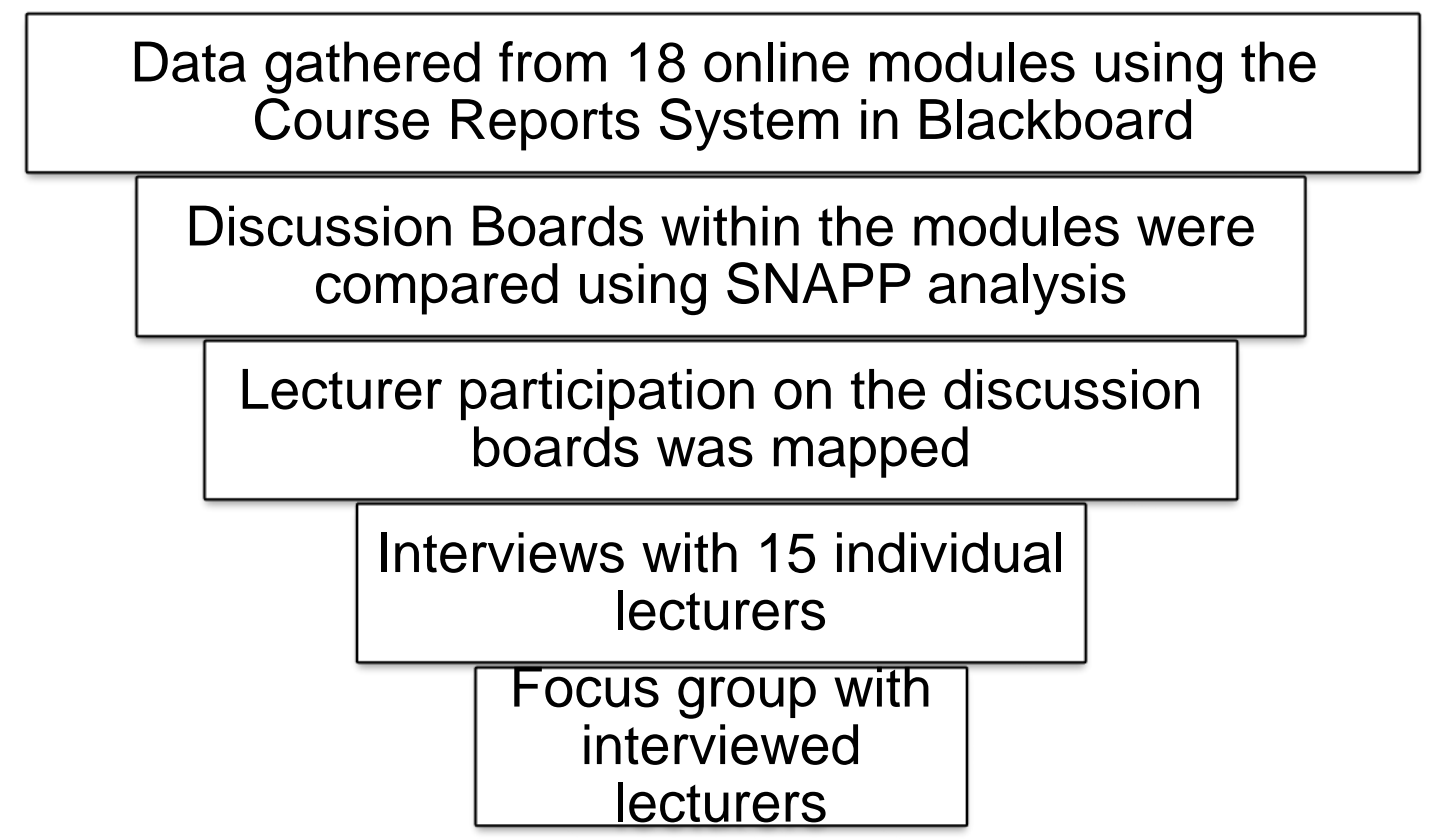

Figure 1. Layers of data collection for research study.

The lecturers the study observed worked at a distributed university in the United Kingdom, teaching on a range of online undergraduate degrees. Data from the university learning management system (LMS) was gathered, which presented the participation patterns of lecturers as they engaged within the online setting. Data was extracted from the LMS through running "course reports" and exported in the form of excel spreadsheets. To access the data, lecturers were approached and asked to take part in the study. Eighteen lecturers enrolled the researcher onto their module space, inviting the researcher to observe the practice and enabling her to run course reports to collect data. Data from the module space of each lecturer was shared with them at the interview stage. Fifteen lecturers were interviewed.

Socio-grams of discussion boards were drawn using SNAPP software, which presented visual representations of the discussion board dialogue (Dawson, 2010). Although social media such as Facebook, Twitter, and Linkedin has become increasingly popular (Lambert \& Fisher, 2013), observations of discussion boards enabled the research to focus on the university's online setting. Some lecturers discussed the use of social media but all lecturers used discussion boards. Socio-grams were generated from 135 discussion boards, situated in 11 of the 18 modules observed (Technical issues with the software prevented the creation of Socio-grams from the remaining seven modules). Dialogue mapping identified posts in relation to whether students or lecturers posted, and visualised strings of dialogue. These were coded to analyse differences in the types of posts lecturers used. 
The data was analysed taking an ethnographic stance - it was used to observe patterns of online participation (Wolpers, Najjar, Verbert, \& Duval, 2007). GPS data has been used in a similar way when observing movements around physical spaces (Christensen, Kraftl, Horton, \& Hadfield-Hill, 2014) and social networks have been observed by visualising online discussions (Dawson, 2010; Gottardo \& Noronha, 2012). Approaching the data qualitatively, the aim was not to quantify or predict action, but instead participation within the online space was observed while identifying qualitative differences. The data allowed, to an extent, immersion in the online world and observation of its rituals (Hammersley \& Atkinson, 2007). While it was not possible to travel to the online setting, the data enabled observation of the participation within that setting, in line with an ethnographic stance (Maneen, 1988). Engaging with the challenge of interpreting and translating these observations adequately, observations drawn from the data were collated and presented to lecturers during the subsequent interviews (Table 1).

Interviews and a focus group were carried out following the analysis of the online data. Interview questions were developed in response to the data analysis and informed by a pilot interview, carried out with a lecturer who also took part in the focus group. Interviews lasted between 35 minutes to one hour. Thirteen face-to-face interviews were conducted, while two used the university video conferencing (VC) system. The interviews were conceived as a process of co-constructing meaning between the interviewer and the interviewee (Gubrium, 2012). Interviewees were asked seven questions (Table 1) and then shown, and asked to respond to, the data relating to the modules on which they taught.

Table 1

Questions Used in Interviews With Online Lecturers

\begin{tabular}{|c|c|}
\hline Number & Interview questions \\
\hline 1 & How would you describe teaching and learning? What is involved? \\
\hline 2 & $\begin{array}{l}\text { What discipline would you describe the modules you teach (relating to this research) as } \\
\text { belonging to? What is the nature of knowledge in that discipline? }\end{array}$ \\
\hline 3 & $\begin{array}{l}\text { I'm looking at collaboration in online environments. How would you describe the nature } \\
\text { of collaboration in an online module? }\end{array}$ \\
\hline 4 & $\begin{array}{l}\text { How would you describe your approach to teaching modules (here insert the relevant } \\
\text { modules the research had observed)? }\end{array}$ \\
\hline 5 & What do you think is the nature of the student experience on an online module? \\
\hline 6 & What collaborative tools do you use on your modules and why? \\
\hline 7 & What do you think is the nature of the student experience on an online module? \\
\hline
\end{tabular}

The subsequent focus group used video conferencing to bring together seven lecturers, in geographically disparate locations. Three lecturers, unable to attend the focus group, commented on a summary of proceedings. The focus group began by the researcher sharing a summary of the interview analysis. Five questions were then posed (Table 2): 
Table 2

Focus Group Questions That Structured the Discussion

\begin{tabular}{|l|l|}
\hline Number & \multicolumn{1}{|c|}{ Focus group questions } \\
\hline 1 & In regards to your own experience does that make sense? \\
\hline 2 & Are there any aspects which you didn't agree with? \\
\hline 3 & $\begin{array}{l}\text { Do you approach discussion boards with a clear rationale? Would you describe your } \\
\text { main aim as being to check or validate understanding, support students to post or } \\
\text { develop dialogue? }\end{array}$ \\
\hline 4 & $\begin{array}{l}\text { How would you describe your role as an online tutor in regards to your presence on a } \\
\text { module? Should you be central to delivering structuring content, part of weekly } \\
\text { discussions or simply available if students have questions? How does an online tutor } \\
\text { enable student learning? }\end{array}$ \\
\hline 5 & $\begin{array}{l}\text { Do you think these findings have any implications for practice? Do they highlight any key } \\
\text { issues in relation to online practice? }\end{array}$ \\
\hline
\end{tabular}

The focus group enabled a dialogic negotiation of meaning (Lambert \& Loiselle, 2008), as lecturers discussed their experiences as a group. Sharing the summary of the interview analysis enabled the focus group to act as a second member checking layer. Following the identification of patterns of participation within the online data, the interviews and focus group were analysed narratively, using an iterative approach that identified themes within the data.

Before proceeding with the research, ethical clearance was granted by the university ethics committee. Data collected from the online space was kept secure; it was not shared in its raw form and all data were made anonymous before being presented in publications or to lecturers. During the interviews, lecturers were only shown data from modules that they had taught and data that they had access to through their own module space. Participants' perspectives were respected and the researchers own positioning within the field was acknowledged. Any evidence used in analysis was made anonymous before being included in any written or verbal presentations.

\section{Results}

The observation drawn presented a rich and varied picture of online practice. Within this, qualitatively different approaches to online teaching, and to facilitating discussion boards, were observed. Presented below are three vignettes that highlight the qualitatively different ways in which lecturers approached online practice. The vignettes are presented in narrative form to highlight the different experiences of the lecturers involved, demonstrating the situated nature of online practice. They do not suggest that any one approach is better than another; rather, they show how epistemological and philosophical differences influence the practice of online lecturers.

The three lecturers were all experienced online practitioners, physically situated in different locations. They each taught predominantly on one of three different undergraduate degree programmes (this 
research looked at modules from four undergraduate degree programmes). Data were collected from two modules; one at Scottish Credit and Qualifications Framework (SCQF) level seven and one at SCQF level nine (first year and third year of undergraduate degrees), for two of the lecturers. For the third lecturer, data were collected on three modules; one at SCQF level seven and two at SCQF level nine. In the vignettes below, the lecturers have been given pseudonyms and all identifiers have been removed for anonymity.

\section{Vignette One - Jenny}

Jenny viewed education as a holistic practice. She spoke about the social and emotional aspects of the learning process and was concerned with the holistic development and well-being of students. When asked about learning and teaching she said:

To me education, learning, and teaching, is much more about these softer outcomes ... it's to do with helping people realise their worth, their capacity in terms of who they are... my role as an educator has to be, I think, about helping students to recognise their potential... the capacity they have to be the best that they can.

The degree in which Jenny taught related directly to a professional community. Students were employed and completing qualifications directly related to their day jobs. The degree attracted a wide range of students, predominantly female, with a mix between mature and "traditional" students. The routes into the degree were varied; many of the students accessed the programme through college-based vocational courses, while others had experienced a large gap of time since engaging with academic study.

The discussion boards on Jenny's modules presented socio-grams with multiple connections between participants:

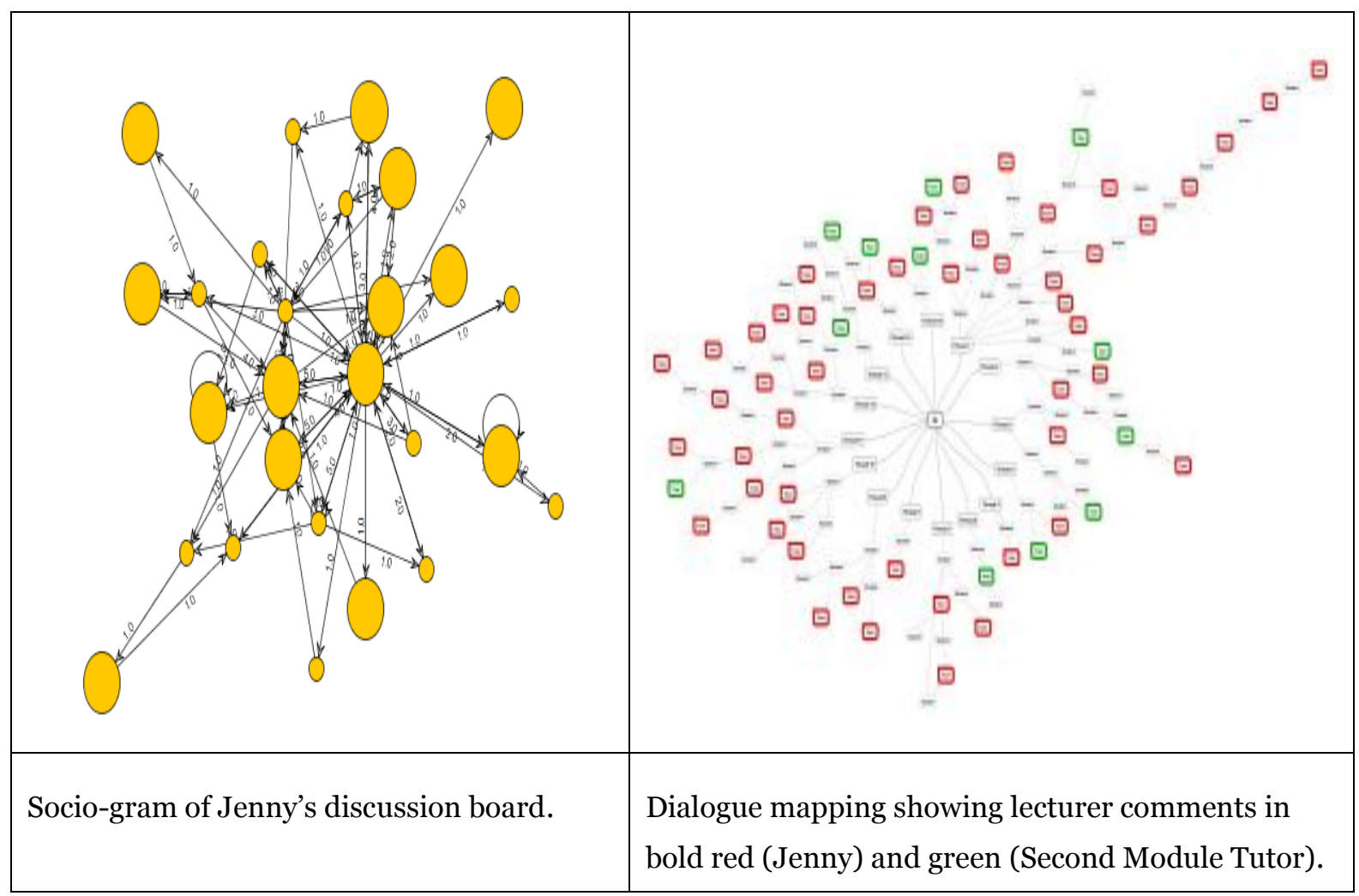

Figure 2. Visualisations of a discussion board: Jenny. 
Jenny took a nurturing approach and responded to students individually, encouraging them, and supporting their participation on the discussion boards. Observations of participatory positioning reflected this. Jenny responded to the majority of student posts (Figure 2) and was recorded with the highest number of posts out of all the lecturers observed. When discussing her facilitation of the discussion boards, and in response to the diagram showing her dialogic participation, Jenny commented: "This is me (identifying the boldly outlined red boxes in Figure 2). I would purposefully go out to interact to this level." Reflecting on this Jenny added: "Presence, social presence is really important ... they're (students) looking for that level of reassurance (response from tutor).”

Although Jenny was an experienced online lecturer, she still found the online context challenging:

In the face-to-face classroom, it's easier (facilitating discussion) because of the immediacy ... you're not getting that level of facilitation that you can immediately in face-to-face ...maybe as a tutor I'm trying to compensate for that, and that's why you're seeing me as present as much as I am.

The online space mediated Jenny's practice through its lack of non-verbal and para-verbal feedback. The lack of feedback led to interactions feeling constrained. Jenny was always available for her students and worked hard to project her presence into the online space. As well as frequent discussion board communications, Jenny responded quickly to e-mails and was "available 24/7" (Focus Group), supporting her students as they progressed through the modules. The use of collaborative activities in Jenny's teaching was motivated by the holistic needs of students:

I think collaboration is the key in terms of helping students to feel engaged with the learning process ... I think as a tutor my role is to try to get them to recognise that there's this wider community that they can engage with and if they reach out to engage with the wider community that makes them feel more part of the bigger picture, part of something that's going on rather than I'm sitting at home on my own.

Collaborative activities, for Jenny, provided an opportunity to engage students in a learning community. The social and emotional aspects of the learning process were important.

\section{Vignette Two - David}

David worked on a degree in a scientific discipline and was passionate about his subject. The degree on which he taught had the same wide ranging student demographic as Jenny's. In contrast to Jenny's programme, David's was more subject-orientated. It related to future professions, but was not firmly connected to one particular professional community. David described the progression of teaching as it developed over the three years of the degree:

In first year it's just science and it's just factual ... we don't try to explore why that is, the reasons behind it, debate about it ...there's a heavy dose of science in all of the (modules), however by third year I'm trying to teach them that they need to broaden their horizons beyond just the science ... there's implications in everything we do ... in politics ... computing, we're using computer models ... socio-economic aspects... it's multi-disciplinary. 
David's passion for his subject shone through in the interview discussion: "Everyone on this earth should know for example ... it's a fundamental fact." The language was emotive, the knowledge which the degree taught was important.

Sociograms drawn from David's discussion boards and the related dialogue maps (Figure 3) showed David to be centrally located in the dialogue, reflecting the traditional classroom dialogic pattern of question, answer, and comment (Nuthall, 2007).

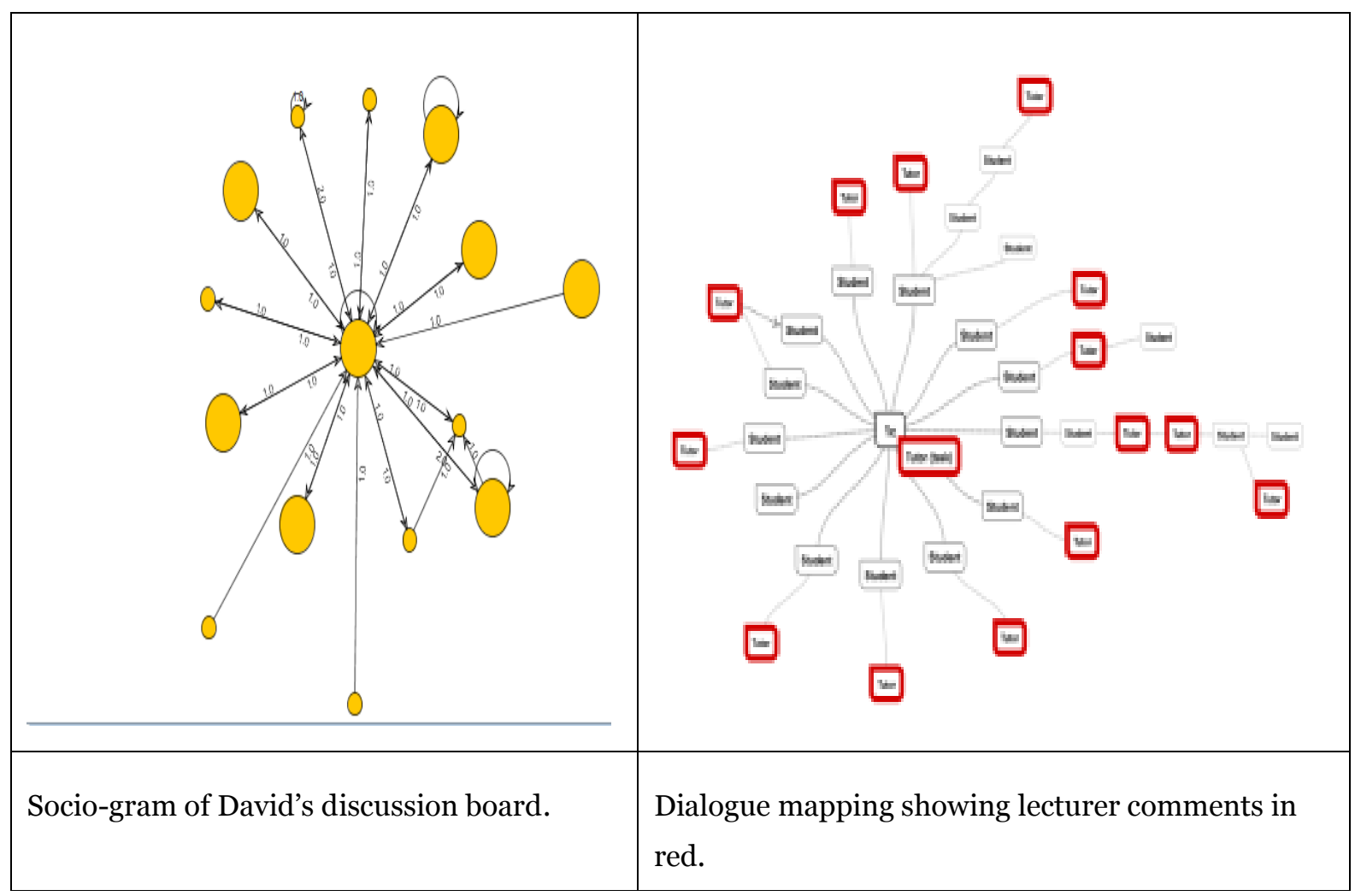

Figure 3. Visualisations of a discussion board: David.

David positioned himself in the centre of the dialogue, setting questions and responding to the answers posted by students. David shared Jenny's perception of online collaboration being a challenge: "(Collaboration) it's quite iffy ... personally I prefer VC (video-conferencing) much more because they see me and they put a name to my face."

Jenny had compared online interactions with her previous face-to-face teaching; David compared them to his teaching using video-conferencing. In both examples, the humanness of the other medium, the immediacy of the face-to-face, and seeing people's faces on VC, emphasised what was lacking in the text-based communications of the online context. David's response to this, though, was quite different to Jenny's:

I make it obligatory for them to contribute to the discussion board each week because $40 \%$ of their grade depends on a reflection of contributions to the discussion board, however, I pick four weeks for them to talk about, reflect on ... but I don't tell them until the end of term which four weeks ... they must contribute to all of the weeks even though I'm only going to pick four of them at the end for them to reflect on, this works really well. 
David was responsive to the feelings of his students; he spoke of how they were often scared to post on discussion boards. He enjoyed the rapport he built with classes through VC sessions and he felt the online context constrained this: "In the online environment it's a lot more difficult ... there's not as strong a rapport."

Although both David and Jenny identified similar constraints to the use of collaborative activities when teaching online, their responses were quite different.

\section{Vignette Three - Laura}

Laura described teaching and learning as a relationship:

Well it's a relationship, I think that's absolutely critical, it's the nature of that relationship that will make it, not entirely but certainly have a strong lean on how effective it is ... the students respond to the relationship and to the personality of the person who's doing the teaching ... Now that's not, that's not across the board, there are some very well-motivated students that never want to talk to you but in the main I would suggest it's about relationships.

Laura's modules were based in a different degree to Jenny's or David's, although first year modules from Jenny's degree were optional in Laura's and vice-versa. As with all three of the tutors presented in these vignettes, Laura was experienced in relation to teaching online. When asked about the nature of online collaboration, Laura highlighted its pedagogic potential:

The nature of collaboration, I think I'd start by saying it's not instinctive and therefore it has to be contrived. The importance of collaboration, if we start from the point that collaboration is a part of this relationship of learning and teaching then to collaborate is about developing knowledge, learning, and constructing knowledge in a group.

Laura presented a pedagogic approach which reflected a social view of learning (Bruner, 1996; Wenger, 1998), in which collaborative activities developed and constructed knowledge. In describing collaboration within the online environment as contrived, she highlighted the mediating role of the online space. In discussion she suggested that face-to-face collaboration was more natural: "When you sit in a classroom next to somebody and there's a kind of instinctive chatting."

Facilitating discussion boards Laura was informed by a clear philosophy; as well as actively engaging with her own online teaching, Laura had taken part in research, related to student's use of discussion boards;

If the lecturer stays out in the early stages the conversation reaches consensus and stops, the job of the lecturer in an online discussion is to take it outwards, to bring in a new idea, to ask a question and in some cases to share opinions, disclosure is really important in there as well ... it's also being responsive to what's going around, what the students are interested in.

This was reflected in the data drawn from discussion boards on Laura's modules (Figure 4). She positioned herself within the dialogue, and directed the students to reply to a single thread, rather than starting new ones. 


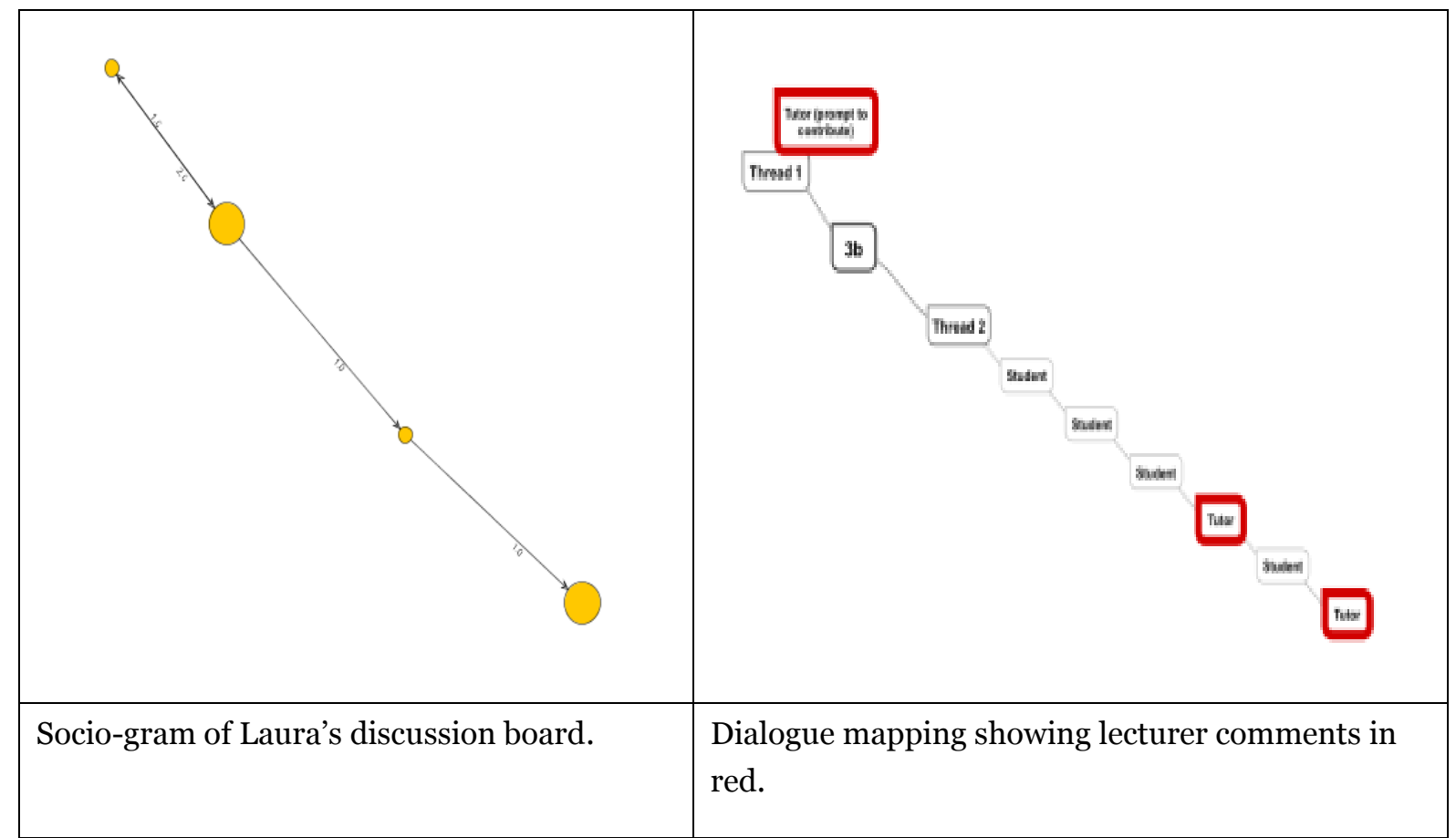

Figure 4. Visualisations of a discussion board: Laura.

Sociograms from all of Laura's modules displayed single lines of dialogue (Figure 4). Laura took a directive approach and positioned herself within the discussion, acting to stimulate and generate student's continued dialogue.

Laura's posts were the longest of the three lecturers presented here. Being positioned within the dialogue, Laura drew together the discussion, added new thoughts, or introduced a new concept and invited responses. Laura reflected that not all students wanted to join in on the discussion boards; some were quite happy to work alone. However, she felt that the lecturer's role should be active. She discussed the use of chat rooms (synchronous text-based online discussions) and the success of these, when students engaged. Chat rooms were a regular occurrence on the modules which Laura led. She felt that the role of the lecturer, as in a face-to-face class, was to engage students with the module content, to "teach": "The tools are the same, it's the personality, it's the materials, it's the engagement but you're doing it in a different setting."

\section{Discussion}

Frameworks such as the Community of Inquiry (Garrison et al., 2000), enable understanding of online learning and support the development of collaborative constructivist approaches (Garrison, 2012). However, the focus on the learner overlooks the diversity of experience that lecturers bring to their teaching. Instructor presence; "the intersection of social and teaching presence" (Richardson et al., 2015, p. 250) has been defined as the pedagogic and social positioning of the tutor. This research highlights the ways in which instructor presence influences dialogic activity in online settings, as lecturers enact qualitatively different approaches to online facilitation. Online discussion boards provide spaces for knowledge construction (Bruner, 1996; Garrison et al., 2000; Redmond, Devine, \& Basson, 2014) and the negotiation of meaning (Wenger, 1998; Akyol \& Garrison, 2011). These 
experiences are shaped by the philosophy of the facilitating lecturer, reflecting their pedagogy and purpose.

The dialogic patterns of discussion board interactions can be seen to reflect the cultural and social situation of the facilitating lecturer. In Vignette One, the lecturer is observed to respond to each student comment, reflecting her philosophy. Describing her role, the lecturer focused on the affective aspects of the learning experience and the importance of students' feelings about their own ability. The positioning she takes within the dialogue reflects this philosophy as each student is supported with a response that focuses on encouraging and valuing their participation. This dialogic pattern can be seen to reflect the philosophy of the lecturer and the values and beliefs of the professional community in which she was working; a community which was "nurturing," valuing the holistic and emotional experience of learners. Comparing this with the positioning of the lecturer in Vignette Two, a qualitatively different approach to facilitation is observed. In the dialogic patterns observed here, the lecturer positions himself in relation to knowledge, confirming, challenging, or consolidating the students' answers. This reflects the values and beliefs of the professional community in which the lecturer is situated; a community which is informed by a scientific epistemology and a focus on knowledge. The lecturer in Vignette Two was aware of the feelings of students and the ways these might influence their interactions on discussion boards. However, the dialogic structure reflected the values, beliefs, and epistemology of his practice, as he positioned himself in a traditional teaching role in relation to his students.

The vignettes present a simplified picture in their presentation of the variance of lecturers' approaches to online facilitation, highlighting the situated nature of online practice. Previous research has highlighted the influence of lecturers on the student experience in both face-to-face (Karagiannopoulou \& Entwistle, 2013), and online settings (Lameras, 2012; Owens, 2012). The findings here suggest that the positions lecturers take in online dialogue influence the student experience. Lecturers' philosophy, their values, and beliefs are reflected in the ways they facilitate online dialogue.

Pedagogic approach can also be seen to position lecturers. In Vignette Three, the lecturer focused on creating dialogue, actively shaping the dialogue to create social interactions, reflective of a social constructivist pedagogy. In all three examples lecturers' facilitation of the discussion boards created a dialogic pattern reflective of the professional community in which lecturers engaged. This enabled the negotiation of meaning (Wenger, 1998) and the construction of understanding (Bruner, 1996), within a social context. The online dialogue lacked the utterances of face-to-face interactions (Beth, Jordan, Schallert, Reed, \& Kim, 2015) but the underlying structure reflected the genre of the discipline (Bakhtin, 2010) and the "voices" of the professional community (Wertsch, 1991).

Observations of the complete data set showed variations of these approaches. Lecturers were observed to facilitate discussion boards in similar ways throughout the duration of a module, rather than to move between these qualitatively different approaches. This suggested that facilitation was informed, as presented above, by philosophy, purpose, and pedagogy. Future research could further explore the varying competencies of online lecturers, in relation to these differing approaches to facilitation. Garrison (2012) argued that the Community of Inquiry framework (CoI) (Garrison et al., 2000) was designed for online learning informed by a collaborative constructivist pedagogy. In relation to the CoI presences, all of the lecturers interviewed in the wider research were acutely aware of social presence (Annand, 2011). Jenny, David, and Laura used inclusive pronouns in discussion board comments and highlighted the importance of students being aware of other online participants as people. Their 
awareness of teaching presence and cognitive presence, however, differed as it reflected differing pedagogies and philosophical positioning.

Laura (Vignette Three) reflected the collaborative constructivist approach of the CoI (Garrison, 2012) in her focus on dialogue and relationships. David focused on knowledge when teaching, this was potentially not a reflection of a transmissive pedagogy (Gonzalez, 2010), but of his scientific epistemology. For Jenny, the focus on affect reflected extensions of the CoI, which have added emotional presence (Stenborn, Jansson, \& Hulkko, 2016) and an online pedagogy that considered the emotional experience of students. Drawing these approaches together with research from the wider study three foci were identified, which related to lecturers' approaches to discussion board communications: knowledge, affect, and dialogue (Figure 5).

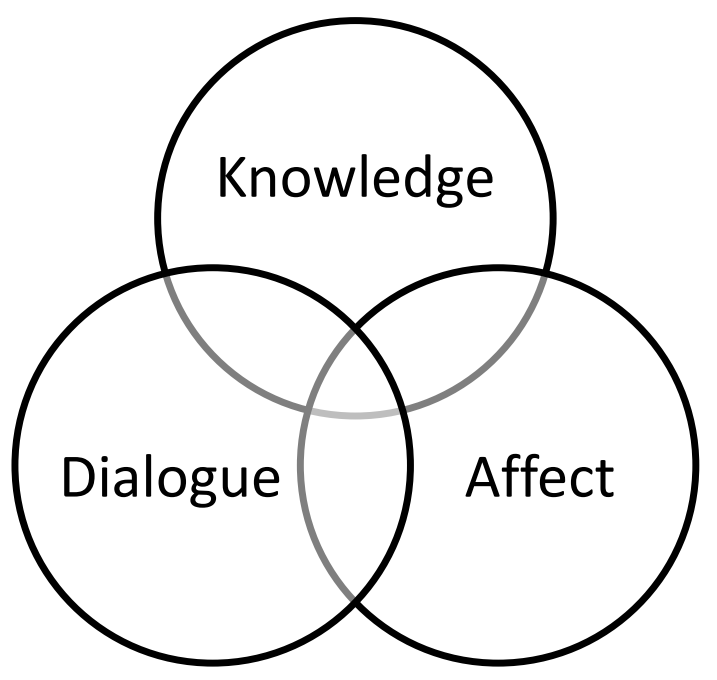

Figure 5. Knowledge, affect, and dialogue: Foci of online practice.

These three foci were observed to be mutually constituting (Rogoff, 2008); one could be brought into focus but the rest were still there, and influenced by any action taken. Although lecturers might foreground a particular foci (as in the three vignettes presented above), they were still aware of the other two. In contrast to the CoI (Garrison et al., 2000), this framework does not reflect a particular pedagogic approach (Garrison, 2012), rather it describes the experience of online teaching.

For online lecturers, consideration of their positioning within the frame of reference of the three foci (Figure 5) has the potential to develop their awareness of the purpose, philosophy, and pedagogy they enact. This, in turn has the potential to develop the student experience in epistemologically relevant and culturally appropriate ways. Further research could explore the social and cultural nature of online spaces, and develop lecturers' awareness of the factors that influence their online facilitation.

\section{Conclusion}

Lecturers' facilitation of online modules reflects their philosophy, pedagogy, and purpose. Students are positioned in relation to the pedagogic focus of the lecturer, through the dialogic structure of online discussions. Online dialogue reflects the cultural values and beliefs of the professional community, or discipline of the lecturer, thus implicitly enabling students to negotiate meaning in culturally relevant 


\section{Coker}

ways. Online practice, like face-to-face instruction, is situated by the cultural spaces in which lecturers' act. The cultural values and beliefs of professional communities and the informing epistemologies are enacted through the interactions between participants as they engage in, and through, online spaces. The online setting mediates practice in ways which are fundamentally different to face-to-face settings, challenging physical and temporal boundaries. To develop online practice and ensure that the learning which takes place is high-quality and comparable to the face-to-face setting, it is important to consider the philosophy, purpose, and pedagogy of the online lecturer. 


\section{Purpose, Pedagogy and Philosophy: "Being" an Online Lecturer \\ Coker \\ References}

Åkerlind, G. S. (2004). A new dimension to understanding university teaching. Teaching in Higher Education, 9(3), 363-375. https://doi.org/10.1080/1356251042000216679

Akyol, Z., \& Garrison, D. R. (2011). Assessing metacognition in an online community of inquiry. The Internet and Higher Education, 14(3), 183-190.

https://doi.org/10.1016/j.iheduc.2011.01.005

Annand, D. (2011). Social presence within the community of inquiry framework. The International Review of Research in Open and Distance Learning, 12(5), 40-56. http://dx.doi.org/10.19173/irrodl.v12i5.924.

Arbaugh, J. B. (2014). System, scholar or students? Which most influences online MBA course effectiveness? Journal of Computer Assisted Learning, 30(4), 349-362. https://doi.org/10.1111/jcal.12048

Bakhtin, M. M. (2010). Speech genres and other late essays (V. W. McGee, C. Emerson, \& M. Holquist, Trans.). Austin: University of Texas Press.

Beth, A. D., Jordan, M. E., Schallert, D. L., Reed, J. H., \& Kim, M. (2015). Responsibility and generativity in online learning communities. Interactive Learning Environments, 23(4), 471484. https://doi.org/10.1080/10494820.2013.788035

Bruner, J. (1996). The culture of education. London, UK: Harvard University Press.

Cho, M. H., \& Cho, Y. (2014). Instructor scaffolding for interaction and students' academic engagement in online learning: Mediating role of perceived online class goal structures. The Internet and Higher Education, 21, 25-30. https://doi.org/10.1016/j.iheduc.2013.10.008

Christensen, P., Kraftl, P., Horton, J., \& Hadfield-Hill, S. (2014). New urbanisms, new citizens: Children and young people's everyday life and participation in sustainable communities (RES-062-23-1549). Retrieved from https://gtr.ukri.org/project/E6D393D9-917B-4B8FB899-B18EFC1DE390

Cohen, L., Manion, L., \& Morrison, K. (2013). Research methods in education. London: Routledge.

Dawson, S. (2010). 'Seeing' the learning community: An exploration of the development of a resource for monitoring online student networking. British Journal of Educational Technology, 41(5), 736-752. https://doi.org/10.1111/j.1467-8535.2009.00970.x

Fereday, J., \& Muir-Cochrane, E. (2006). Demonstrating rigor using thematic analysis: A hybrid approach of inductive and deductive coding and theme development. International Journal of Qualitative Methods, 5(1), 80-92. https://doi.org/10.1177/160940690600500107

Garrison, D. R. (2012). Article Review: Social presence within the community of inquiry framework. The International Review of Research in Open and Distributed Learning, 13(1), 250-253. http://dx.doi.org/10.19173/irrodl.v13i1.1184 
Garrison, D. R., Anderson, T., \& Archer, W. (2000). Critical inquiry in a text-based environment: Computer conferencing in higher education. The Internet and Higher Education, 2(2), 87105. https://doi.org/10.1016/S1096-7516(00)00016-6

González, C. (2010). What do university teachers think eLearning is good for in their teaching? Studies in Higher Education, 35(1), 61-78. https://doi.org/10.1080/03075070902874632

Gottardo, E., \& Noronha, R. V. (2012, October). Social networks applied to distance education courses: analysis of interaction in discussion forums. In Proceedings of the 18th Brazilian Symposium on Multimedia and the Web (pp. 355-358). São Paulo, Brazil.

Gubrium, J. F., Holstein, J. A., Marvasti, A. B., \& McKinney, K. D. (Eds.). (2012). The SAGE handbook of interview research: The complexity of the craft. London: Sage.

Guillaume, C., Lalanne, D., Lavoue, E., Lund, K., Molinari, G., Ringeval, F., \& Weinberger, A. (2016) 'Grand Challenge Problem 2: Adaptive Awareness for Social Regulation of Emotions in Online Collaborative Learning Environments'. In J. Eberle, K. Lund, P. Tchounikine \& F. Fischer (Eds.), Grand challenge problems in technology-enhanced learning II: MOOCs and beyond. (pp. 13-16) Cham: Springer International Publishing. https://doi.org/10.1007/978-3-319$12562-6 \quad 3$

Hammersley, M., \& Atkinson, P. (2007). Ethnography: Principles in practice. London: Routledge.

Joksimovic, S., Gasevic, D., Kovanovic, V., Adesope, O., \& Hatala, M. (2014). Psychological characteristics in cognitive presence of communities of inquiry: A linguistic analysis of online discussions. The Internet and Higher Education, 22, 1-10.

https://doi.org/10.1016/j.iheduc.2014.03.001

Karagiannopoulou, E., \& Entwistle, N. (2013). Influences on personal understanding: Intentions, approaches to learning, perceptions of assessment and a 'meeting of minds'. Psychology Teaching Review, 19(2), 80-96.

Kehrwald, B. (2008). Understanding social presence in text-based online learning environments. Distance Education, 29(1), 89-106. https://doi.org/10.1080/01587910802004860

Kim, Y., Glassman, M., \& Williams, M. S. (2015). Connecting agents: Engagement and motivation in online collaboration. Computers in Human Behavior, 49, 333-342. https://doi.org/10.1016/j.chb.2015.03.015

Kyei-Blankson, L., Ntuli, E., \& Donnelly, H. (2016). Establishing the importance of interaction and presence to student learning in online environments. World Journal of Educational Research, 3(1), 48- 65. http://dx.doi.org/10.22158/wjer.v3n1p48

Laffey, J., Lin, G. Y., \& Lin, Y. (2006). Assessing social ability in online learning environments. Journal of Interactive Learning Research, $17(2), 163$. 
Lambert, J. L., \& Fisher, J. L. (2013.) Community of inquiry framework: Establishing community in an online course. Journal of Interactive Online Learning, 12 (1), 1-16.

Lambert, S. D., \& Loiselle, C. G. (2008). Combining individual interviews and focus groups to enhance data richness. Journal of Advanced Nursing, 62(2), 228-237.

Lameras, P., Levy, P., Paraskakis, I., \& Webber, S. (2012). Blended university teaching using virtual learning environments: conceptions and approaches. Instructional Science, 4O(1), 141-157. https://doi.org/10.1007/s11251-011-9170-9

Maanen, J. V. (1988). Tales of the field: On writing ethnography. London, UK: University of Chicago Press.

Nuthall, G. (2007). The hidden lives of learners. Wellington, NZ: NZCER Press

Owens, T. (2012). Hitting the nail on the head: The importance of specific staff development for effective blended learning. Innovations in Education and Teaching International, 49(4), 389400. https://doi.org/10.1080/14703297.2012.728877

Palloff, M. R., \& Pratt, K. (2004, August). Learning together in community: Collaboration online. In 2oth Annual Conference on Distance Teaching and Learning, Madison, Wisconsin. Retrieved from http://www.teacamp.eu/moodle2/pluginfile.php/1706/mod resource/content/1/C1NN/Lear ning Together_in_Community Collaboration_Online.pdf

Park, J. Y. (2015). Student interactivity and teacher participation: An application of legitimate peripheral participation in higher education online learning environments. Technology, Pedagogy and Education, 24(3), 389-406. https://doi.org/10.1080/1475939X.2014.935743

Pozzi, F., Ceregini, A., Ferlino, L., \& Persico, D. (2016). Dyads versus groups: Using different social structures in peer review to enhance online collaborative learning processes. The International Review of Research in Open and Distributed Learning, 17(2). http://dx.doi.org/10.19173/irrodl.v17i2.2107.

Redmond, P., Devine, J., \& Bassoon, M. (2014). Exploring discipline differentiation in online discussion participation. Australasian Journal of Educational Technology, 3o(2).

Richardson, J. C., Koehler, A. A., Besser, E. D., Caskurlu, S., Lim, J., \& Mueller, C. M. (2015). Conceptualizing and investigating instructor presence in online learning environments. The International Review of Research in Open and Distributed Learning, 16(3). http://dx.doi.org/10.19173/irrodl.v16i3.2123.

Rogoff, B. (2008). Observing sociocultural activity on three planes: Participatory appropriation, guided participation, and apprenticeship. In K. Hall, P. Murphy, \& J. Soler Pedagogy and practice: Culture and identities (pp. 58-74). London, UK: SAGE Publications Ltd. 
Slagter van Tryon, P.J. \& Bishop, M.J. (2006). Identifying "E-mmediacy" Strategies for Web-Based Instruction: A Delphi Study. Quarterly Review of Distance Education, 7(1), 49-62. Retrieved from https://www.learntechlib.org/p/106687/.

Stenborn, S. Jansson, M. \& Hulkko, A. (2016). Revising the community of inquiry framework for the analysis of one-to-one online learning relationships. The International Review of Research in Open and Distributed Learning, 17(3). http://dx.doi.org/10.19173/irrodl.v17i3.2068

Stott, P. (2016). The perils of a lack of student engagement: Reflections of a "lonely, brave, and rather exposed” online instructor. British Journal of Educational Technology, 47(1), 51-64. http://dx.doi.org/10.1111/bjet.12215

Wenger, E. (1998). Meaning in communities of practice: Learning, meaning and identity. Cambridge, UK: Cambridge University Press.

Wertsch, J. V. (1991). Voices of the mind: A sociocultural approach to mediated action. Cambridge, MA: Harvard University Press.

Wolpers, M., Najjar, J., Verbert, K., \& Duval, E. (2007). Tracking actual usage: The attention metadata approach. Educational Technology \& Society, 10(3), 106-121.

\section{Athabasca}

University

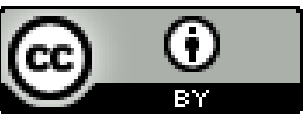

